\title{
Performance Evaluation Zeta Converter Using PI Controller for Energy Management in DC Nanogrid Isolated System
}

\author{
Farid Dwi Murdianto ${ }^{1, a, *}$, Indhana Sudiharto ${ }^{2, b}$, Eni Wulandari ${ }^{3, c}$ \\ ${ }^{1}$ Department of Electrical Engineering, Politeknik Elektronika Negeri Surabaya, Jl. Raya ITS, Keputih Sukolilo 60111, \\ Indonesia \\ a, ${ }^{*}$ farid@ pens.ac.id (Corresponding Author), ${ }^{\mathrm{b}}$ indhana@ pens.ac.id, ${ }^{\mathrm{c}}$ eni124@ gmail.com
}

\begin{abstract}
Renewable energy is needed as an alternative energy source. One of the implementations of renewable energy is the Solar Power Plant (SPP). SPP is a component that uses solar cells to convert solar energy into electrical energy. Unfortunately, the output power of this solar cell depends on the intensity of the light which causes the output power to enter the load to be unstable. Sometimes the $P V$ power decrease because of the shading effect. From this problem a converter is needed to keep the system output voltage. The converter used in this research is the zeta converter. This Zeta converter can operate like a buck boost converter. The output of the system used is not stable. Therefore to stabilize it requires good control. In this paper using PI controller to control this system in order to keep the output system stable. 3. The error generated using the PI Control on the system is only $0.34 \%$.
\end{abstract}

\section{Keywords-Photovoltaic, Zeta Converter, PI Controller}

\section{Introduction}

In this modern era, technology is developing very rapidly. Many household appliances and other supporting equipment even more require electrical energy. While most of people still using electrical energy from PLN that's the fuels using fossil fuels. Therefore, the need for electrical energy consumption is increasing. From the increasing demand for electrical energy causes the depletion of fossil fuels. Because basically this fossil fuel is a fuel that cannot be renewed so that when this fuel runs out it can cause the electricity supply to run out. The role of using renewable energy can help overcome and contribute to energy generation. In addition, renewable energy has many advantages, one of which is not causing pollution. There are many types of renewable energy, however, what is currently being developed is solar cell. Solar cell is a component that converts sunlight into DC electrical energy. The power is produced by PV depends on the intensity of light and the temperature that hits the surface of the PV. So that, when the amount of light intensity decreases, the power is produced by PV will also be decreased. Based on this problem, a system is required to stabilize the output power for example the used of Zeta converter, which is one of the converters that can transfer power from PV [1]-[3].

\section{Research Methodology}

This proposed system requires a converter that can increase and decrease the output voltage. The Zeta converter is a non-isolated converter that has the same operating mode like the buck-boost converter [4]. The output voltage of this converter is maintained stable. Therefore, control is required to keep the output voltage stable.

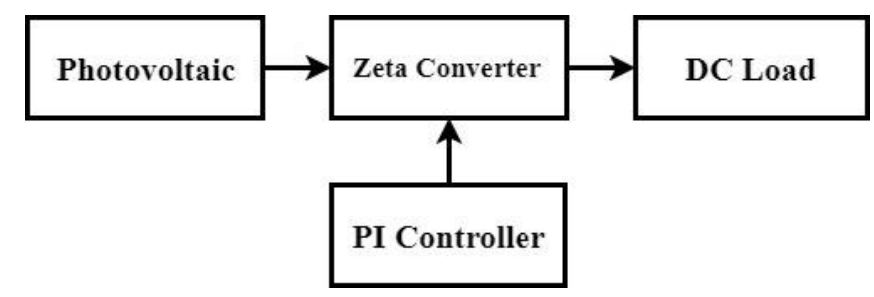

Figure 1. Overall System to Evaluate Performance PI Controller

The control used in this research is the PI controller. This Research is aimed to evaluate the performance PI Controller to manage the dynamic energy from PV. 


\section{A. Modelling of Photovoltaic Module}

Solar cells are energy converters made from semiconductor devices. Some solar cells are assembled into solar panels that can convert solar energy into dc (direct current) electrical energy with a certain capacity according to the type of material and the area of the solar module [5]-[6]. Therefore, the using of more solar panels in areas that are not supplied by PLN (Indonesian Power Supplier Company) is suitable or could become a backup energy when the main electricity source is not available. The equivalent circuit of PV is shown in Figure 2.

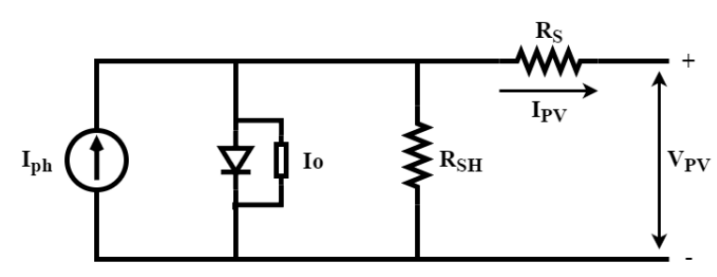

Figure 2. Equivalent circuit of Photovoltaic

The mathematical equation of the PV module can be expressed as [4]:

$I_{p v}=N_{p} \cdot I_{p H}-N_{p} \cdot I_{o}\left[\exp \left(\frac{q\left(V_{p v}+R_{s} \cdot I_{P V}\right)}{A \cdot K \cdot T \cdot N_{s}}\right)-1\right]-N_{p} \cdot\left(\frac{V_{P V}+R_{S}+I_{P V}}{N_{S} \cdot R_{S H}}\right)$

where:

Ipv = output power pv module (A)

$\mathrm{Vpv}=$ output voltage $\mathrm{PV}(\mathrm{V})$

$\mathrm{IPH}=$ generated current $(\mathrm{A})$

IO $=$ current reverse diode $(\mathrm{A})$

Rs $=$ resistance series solar cell $(\mathrm{ohm})$

$\mathrm{RSH}=$ resistance shunt solar cell $(\mathrm{ohm})$

$\mathrm{NP}=$ number of parallel solar cell

$\mathrm{NS}=$ number of series solar cell

$\mathrm{Q}=$ electronic charge $(1.6 \times 10 \neg-19 \mathrm{C})$

$\mathrm{K}=$ constant boltzman $(1.38 \times 10 \neg-23 \mathrm{~J} / \mathrm{K})$

Table I shows data on solar panels with a maximum power of 100 Watt peak.

Table 1. Specification of Photovoltaic

\begin{tabular}{|l|l|}
\hline \multicolumn{1}{|c|}{ Parameters } & Specification \\
\hline Maximum Power (Pmax) & $100 \mathrm{~W}$ \\
\hline Current at Pmax (Imp) & $5.81 \mathrm{~A}$ \\
\hline Voltage at Pmax(Vmp) & $17.2 \mathrm{~V}$ \\
\hline Short circuit Current(Isc) & $6.46 \mathrm{~A}$ \\
\hline
\end{tabular}

\begin{tabular}{|l|l|}
\hline Open circuit Voltage(Voc) & $21.6 \mathrm{~V}$ \\
\hline Temperature coeffecient of Voc & $-0.38 \% /{ }^{\circ} \mathrm{C}$ \\
\hline Temperature coeffecient of Isc & $0.065 \% /{ }^{\circ} \mathrm{C}$ \\
\hline
\end{tabular}

\section{B. Modelling of Zeta Converter}

The zeta converter topology provides a positive output voltage from the input voltage whose output voltage changes up and down. The Zeta converter is another option for regulating an intermittent input voltage. This Zeta converter is run under the Continuous Conduction Mode (CCM) condition [7].

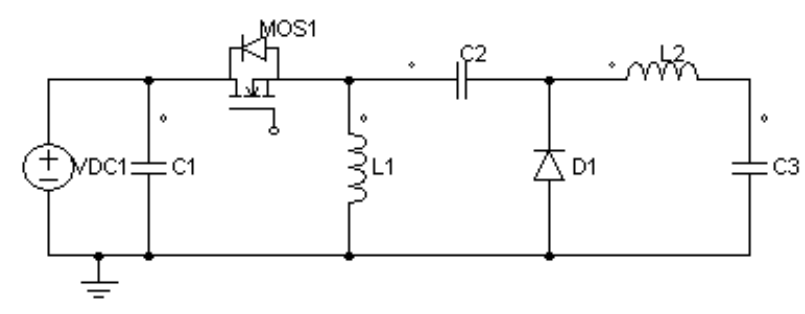

Figure 3. Zeta Converter Circuit

A Zeta converter typically has two inductors as shown in figure 3 . The operation principle of the Zeta Converter can be elaborated as the following description.

When MOS1 is off, the voltage passing through L1b must be output voltage during parallel with the output capacitor. As long as the output capacitor is charged by the output voltage, the voltage will pass through MOS1 when MOS1 off is $\mathrm{V}_{\text {IN }}+\mathrm{V}_{\text {Out }}$ even though the voltage passing through L1a is $-\mathrm{V}_{\text {OUT }}$ relative to the drain of MOS1. When MOS1 on, the coupling capacitor is charged by $\mathrm{V}_{\text {OUT, }}$, which is connected in series with $\mathrm{L} 1 \mathrm{~b}$, so the voltage passing through $\mathrm{L} 1 \mathrm{~b}$ is $+\mathrm{V}_{\mathrm{IN}}$, and diode D1 is $V_{\text {IN }}+V_{\text {OUT. }}$. From the basic operation, it can calculate the value of the duty cycle of the system. It is assumed that the efficiency value of the circuit is $100 \%$. So the duty cycle value can be calculated using equation (2):

$$
D=\frac{\text { Vout }}{\text { Vin }+ \text { Vout }}
$$

Then duty cycle value must be considered for the selection of components. The value of the selected component can be calculated using equation (3):

$$
\Delta I L(p p)=K \times \operatorname{Iin}
$$




$$
\begin{aligned}
& \operatorname{Cin}(\min )=\frac{D \times \operatorname{Iin}}{\Delta V \operatorname{cin} \times \operatorname{Vin} \times f s w} \\
& C c=\frac{D \times \operatorname{Iin}}{\Delta V c c \times \operatorname{Vout} \times f s w} \\
& \operatorname{Cout}(\min )=\frac{D}{8 \times \Delta V o \times f s w}
\end{aligned}
$$

Where:

$$
\begin{aligned}
& \text { Vin }=\text { input voltage }(\mathrm{V}) \\
& \text { Vout= output voltage }(\mathrm{V}) \\
& \Delta_{\mathrm{IL}}(\mathrm{PP})=\text { max ripple current output. }(\mathrm{A}) \\
& \Delta \text { vout }=\text { ripple output voltage }(\mathrm{A}) \\
& \text { FSW }=\text { switching frequency }(\mathrm{Hz}) \\
& \mathrm{L} 1=\text { inductor } 1(\mathrm{H}) \\
& \mathrm{L} 2=\text { inductor } 2(\mathrm{H}) \\
& \text { Cc }=\text { coupling capacitor }(\mathrm{F}) \\
& \text { Cin }=\text { input capacitor }(\mathrm{F}) \\
& \text { Cout }=\text { output capacitor }(\mathrm{F})
\end{aligned}
$$

Table 2. Specification of Zeta Converter

\begin{tabular}{|l|l|l|l|}
\hline Parameters & Symbol & Value & Units \\
\hline Input voltage zeta mode & $\mathrm{V}_{\text {in }}$ & 60 & Volt \\
\hline Output voltage zeta mode & $\mathrm{V}_{\text {out }}$ & 206 & Volt \\
\hline Ouput Current ripple max & $\Delta \mathrm{IL}_{(\mathrm{PP})}$ & 1.1 & $\mathrm{~A}$ \\
\hline Voltage ripple max & $\Delta_{\text {vout }}$ & 0.206 & Volt \\
\hline Frekuensi switching & $\mathrm{F}_{\mathrm{sw}}$ & 40 & $\mathrm{Khz}$ \\
\hline Inductor 1 & $\mathrm{L} 1$ & 530 & $\mathrm{mH}$ \\
\hline Inductor 2 & $\mathrm{L} 2$ & 530 & $\mathrm{mH}$ \\
\hline Coupling capacitor & $\mathrm{Cc}$ & 100 & $\mathrm{uF}$ \\
\hline Input capacitor & $\mathrm{C}_{\text {in }}$ & 13.78 & $\mathrm{uF}$ \\
\hline Output capacitor & $\mathrm{C}_{\text {out }}$ & 100 & $\mathrm{uF}$ \\
\hline
\end{tabular}

\section{Modelling of PI Controller}

A proportional controller that provides a proportional control action with an error will result in an effect on the rise time and cause an offset error. An integral controller that provides control action proportional to the number of errors will have a good effect in reducing steady state errors but can result in deteriorating transient responses. Knowledge of the effects are caused by each controller that will be used in determining the values of proportional $(\mathrm{Kp})$ and integral reinforcement (Ki). The basic table of knowledge of the relationship between reinforcement and its effect on PI controllers is shown in Table 3 [8]-[10].
Table 3. PI Controller Response

\begin{tabular}{|c|c|c|c|c|}
\hline Variable & Rise Time & Overshoot & $\begin{array}{c}\text { Setling } \\
\text { Time }\end{array}$ & Offset \\
\hline $\mathrm{Kp}$ & Increasing & Decreasing & $\begin{array}{c}\text { Small } \\
\text { Change }\end{array}$ & Occurs \\
\hline $\mathrm{Ki}$ & Decreasing & Increases & Increases & Eliminate \\
\hline
\end{tabular}

Combined proportional control actions and integral control actions will perform the action of proportional and integral control (PI controller). This combination of actions has advantages compared to each of its constituents. The main advantage is that the advantages of each control action and the lack of control action can be overcome. In other words, the overall control elements of $\mathrm{P}$ and $\mathrm{I}$ aim to accelerate the reaction of a system and eliminate offsets [11].

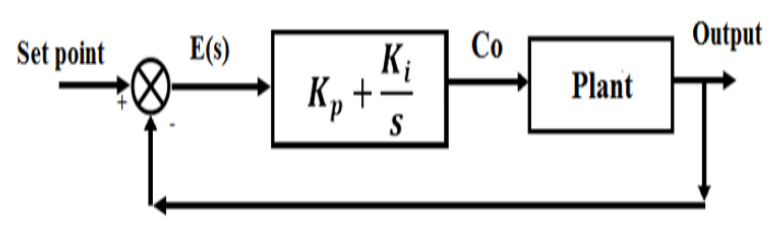

Figure 4. Block diagram of PI Controller

Figure 4 describes the diagram block and PI controller parameters. Where Co is the output signal from PI controller, $\mathrm{Kp}$ is a proportional constant, $\mathrm{Ti}$ is an integral time, $\mathrm{Ki}$ is an integral constant, and $\mathrm{E}(\mathrm{s})$ is an error signal. Tuning on the PI controller is the determination of the magnitudes of $\mathrm{P}$ and $\mathrm{I}$ reinforcements so that good system characteristics are obtained. There are several ways of tuning the PI controller including the Ziegler-Nichols relay feedback method, manual (hand-tuning/trial-error), analytic method with optimization, pole placement, or auto-tune [12]-[13]. The flowchart of the system is shown in figure 5 .

Figure 5 is the flowchart of the system. From the flowchart, it can be recognized that duty cycle defined by using PI controller. When duty cycle is lesser than desirable value, PI controller will increase the duty cycle automatically. 


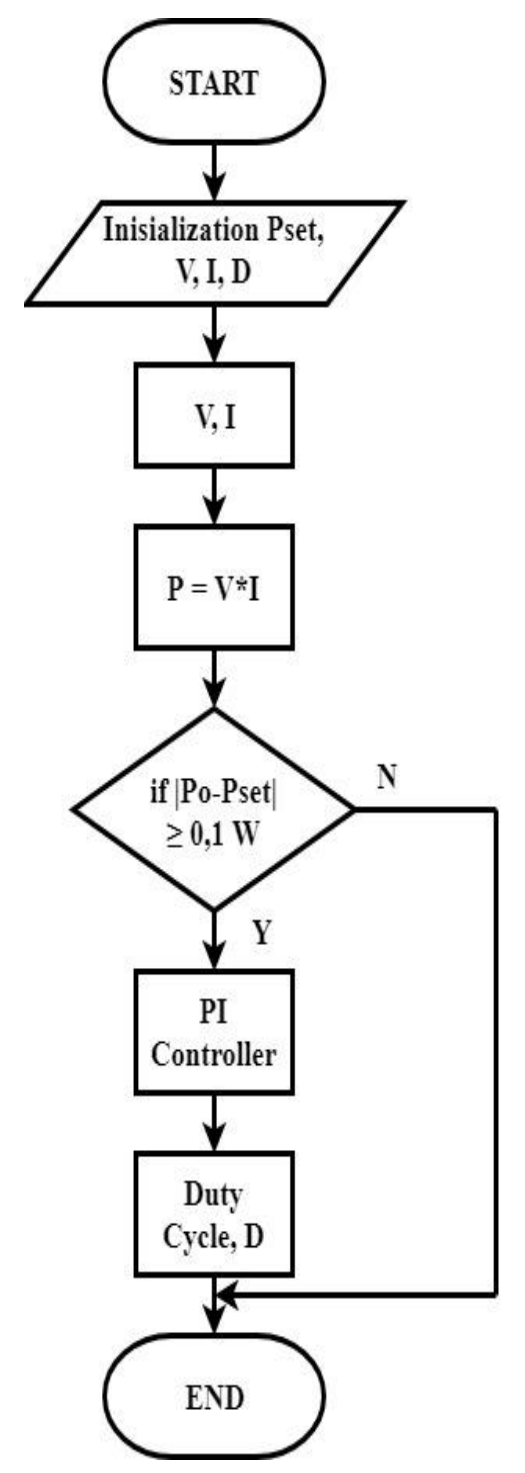

Figure 5. Block diagram of PI Controller

\section{Results and Discussion}

The purpose of this simulation is to test the performance of the system produced by the PI controller. Figure 6 is a simulation result of zeta converter. In this simulation, PVs are used for the supply of the converter. Each PV has specification of 100 WP. The system using $12 \mathrm{PV}$ which $4 \mathrm{PV}$ are arranged in series and $3 \mathrm{PV}$ are arranged in parallel. As a result, the output voltage PV is about 60 Volts.
From figure 6, it has been simulated using $12 \mathrm{PV}$ with a power of $100 \mathrm{WP}$ and a Vmp voltage of 17.2 Volt. This system is simulated using power simulator and after being simulated, it can be seen the form of response from the system when using the control or not.

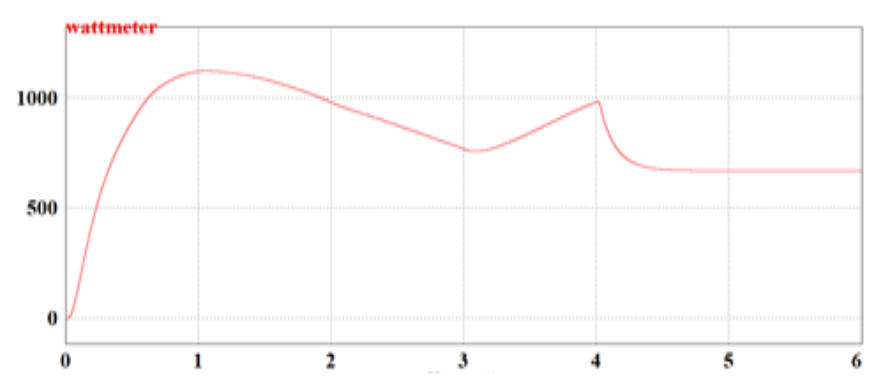

Figure 6. Response system without control when given disturbance

Figure 6 shown the response system without controller but the system is given disturbance at one of the photovoltaic. The setting point of duty cycle that is used same with design of this converter.

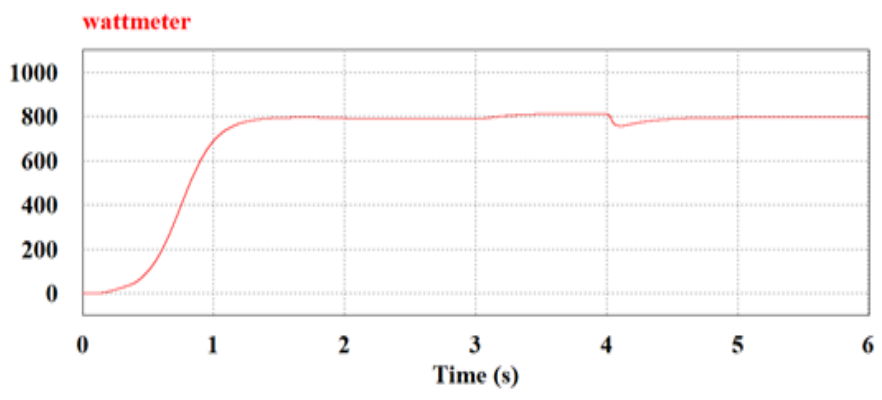

Figure 7. Response system with PI Controller when given disturbance

Figure 7 exhibits the respon system use control and given disturbance at 4 photovoltaics. The disturbance is given in $4 \mathrm{~s}$, the output power is back to set point. Setting point that given in the system is 800 Watt. 


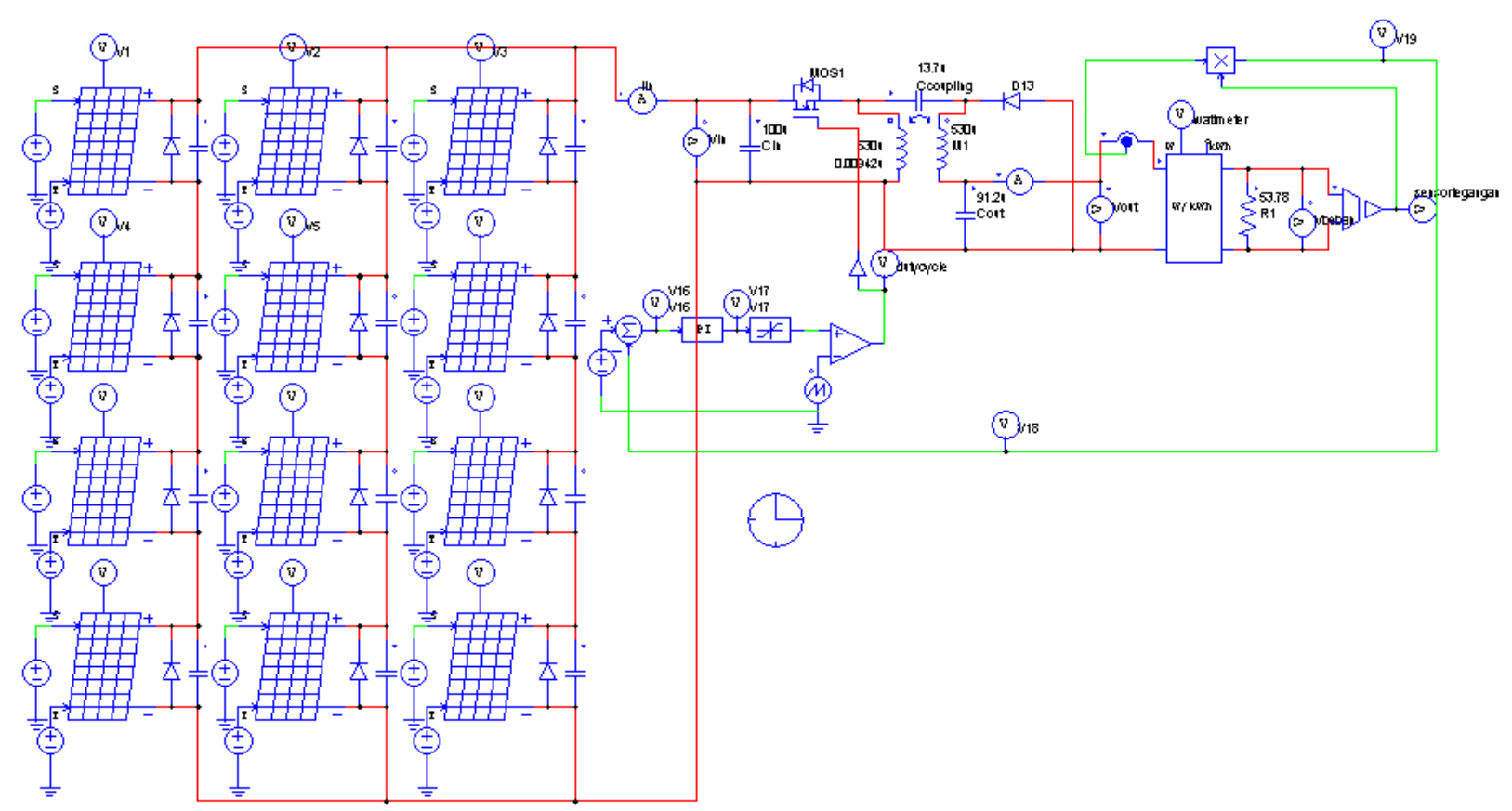

Figure 8. Overall System of Zeta Converter with the connected PVs

The disturbance that is given at $8 \mathrm{PVs}$ with setting point 400 Watt shown in Figure 8. Therefore, from figure 7 and figure 9, it can be observed the comparison results of response system when different disturbance are applied. The disturbance in the figure 7 only at $4 \mathrm{PV}$ but in the figure 9 we give 8 disturbances at $8 \mathrm{PV}$. It is necessary to prove whether the control may work or not.

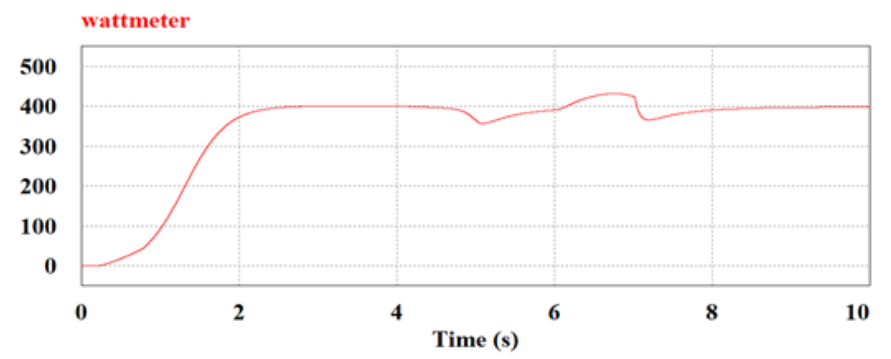

Figure 9. Response system with PI Controller when given disturbance

\section{Conclusion}

A zeta converter simulation that is controlled using a PI controller has been presented and the conclusion based on the simulation results can be drawn as follow:

1. The Reliability of the system using PI control is proven to be able to maintain the power generated as specified.
2. The reliability of the PI control in maintaining the power constant at a specified value has proven to be successful even when tested using interference/disturbance.

3. The error generated using the PI Control on the system is only $0.34 \%$, which is very small and prove that the system working properly.

\section{References}

[1] A. Malhotra, P. Gaur, S. Vij and C. Malhotra, "Design, analysis and performance of zeta converter in renewable energy systems," 2016 3rd International Conference on Computing for Sustainable Global Development (INDIACom), 2016, pp. 2487-2491.

[2] A. M. S. S. Andrade, L. Schuch and M. L. d. S. Martins, "Photovoltaic battery charger based on the Zeta converter: Analysis, design and experimental results," 2015 IEEE 24th International Symposium on Industrial Electronics (ISIE), 2015, pp. 379-384, doi: 10.1109/ISIE.2015.7281498.

[3] Jeff Falin,’Designng DC/DC converter based on ZETA topology”, analog aplication on Texas instrument datasheet, 2008

[4] Rashmi, Manohar J. and Rajesh K.S., "A comparative study and performance analysis of synchronous SEPIC Converter and synchronous Zeta Converter by using PV system with MPPT technique," 2016 IEEE 1st International Conference on Power Electronics, Intelligent Control and Energy Systems (ICPEICES), 2016, pp. 1-6, doi: 10.1109/ICPEICES.2016.7853212.

[5] Rashmi, Manohar J. and Rajesh K.S., "A comparative study and performance analysis of synchronous SEPIC Converter and synchronous Zeta Converter by using PV system with MPPT technique," 2016 IEEE 1st International Conference on Power Electronics, Intelligent Control and Energy Systems (ICPEICES), 2016, pp. 1-6, doi: 10.1109/ICPEICES.2016.7853212. 


\section{INTEK Jurnal Penelitian}

[6] S. Siddiqua, S. Firuz, B. M. Nur, R. J. Shaon, S. J. Chowdhury and A. Azad, "Development of double burner smart electric stove powered by solar photovoltaic energy," 2016 IEEE Global Humanitarian Technology Conference (GHTC), 2016, pp. 451-458, doi: 10.1109/GHTC.2016.7857319.

[7] Soedibyo, B. Amri and M. Ashari, "The comparative study of Buckboost, Cuk, Sepic and Zeta converters for maximum power point tracking photovoltaic using P\&O method," 2015 2nd International Conference on Information Technology, Computer, and Electrical Engineering (ICITACEE), 2015, pp. 327-332, doi: 10.1109/ICITACEE.2015.7437823.

[8] R. Rakhmawati, F. Dwi Murdianto and M. Wildan Alim, "Soft Starting \& Performance Evaluation of PI Speed Controller for Brushless DC Motor Using Three Phase Six Step Inverter," 2018 International Seminar on Application for Technology of Information and Communication, 2018, pp. 121-126, doi: 10.1109/ISEMANTIC.2018.8549749.

[9] R. Rakhmawati, J. Hilmyvarafi Farrasbyan, Suhariningsih and F. Dwi Murdianto, "Performance Robustness of PID Controller in Buck Converter For Cooling System," 2018 International Seminar on Application for Technology of Information and Communication, 2018, pp. 127-132, doi: 10.1109/ISEMANTIC.2018.8549781.
[10] M. Z. Efendi, F. Dwi Murdianto and H. N. Baweani, "Robustness Analysis of PID-Cuckoo Search Algorithm to Voltage Control in Three Phase of Synchronous Generator with Dynamic Load Condition," 2018 International Electronics Symposium on Engineering Technology and Applications (IES-ETA), 2018, pp. 133-138, doi: 10.1109/ELECSYM.2018.8615486.

[11] I. Sudiharto, E. Sunarno, F. D. Murdianto and D. N. Kurniasari, "Robustness Analysis of PI Controller to Constant Output Power with Dynamic Load Condition in DC Nanogrid System," 2018 3rd International Conference on Information Technology, Information System and Electrical Engineering (ICITISEE), 2018, pp. 402-405, doi: 10.1109/ICITISEE.2018.8720976.

[12] A. Jaya, E. Purwanto, M. B. Fauziah, F. D. Murdianto, G. Prabowo and M. R. Rusli, "Design of PID-fuzzy for speed control of brushless DC motor in dynamic electric vehicle to improve steady-state performance," 2017 International Electronics Symposium on Engineering Technology and Applications (IES-ETA), 2017, pp. 179-184, doi: 10.1109/ELECSYM.2017.8240399.

[13] F. D. Murdianto, M. Z. Efendi, K. Widarsono and M. Azizi, "Robustness analysis of PID controller Bidirectional SEPIC/Zeta for Energy Management in DC Nanogrid Isolated System," 2018 3rd International Conference on Information Technology, Information System and Electrical Engineering (ICITISEE), 2018, pp. 406-411, doi: 10.1109/ICITISEE.2018.8721036 